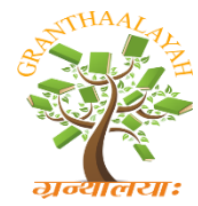

INTERNATIONAL JOURNAL OF RESEARCH GRANTHAALAYAH A knowledge Repository

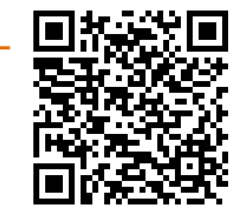

Social

\title{
A STUDY OF ENGLISH READING COMPREHENSION USING CONTENT-BASED INSTRUCTION APPROACH
}

\author{
Panida Khruawan ${ }^{* 1}$, Nutprapha K. Dennis, Ph.D. 2 \\ ${ }^{* 1,2}$ English Department, Graduate School, Ubon Ratchathani Rajabhat University, Thailand
}

DOI: https://doi.org/10.29121/granthaalayah.v5.i1.2017.1911

\begin{abstract}
The purposes of this study were to investigate students' achievement in reading comprehension taught by Content-Based Instruction (CBI) Approach and to study the attitude of students through the approach. The samples of this study were fifty of grade ten students who enrolled English course at Khowangwittayakhom School, Yasothorn. The samples were selected by a simple random sampling. The instrument used in this study consisted of ten content-based instruction lesson plans, reading pre-test and post-test, and questionnaire. The data were analyzed statistically in the form of t-test, arithmetic mean and standard deviation. The research findings as the effectiveness of English reading after using Content-Based Instruction Approach in teaching was significantly higher than before teaching at critical level 0.05 and the students' attitude toward using Content-Based Instruction Approach was at a good level.
\end{abstract}

Keywords: Content-Based Instruction Approach; Reading Comprehension; English Reading.

Cite This Article: Panida Khruawan, and Nutprapha K. Dennis. (2017). "A STUDY OF ENGLISH READING COMPREHENSION USING CONTENT-BASED INSTRUCTION APPROACH." International Journal of Research - Granthaalayah, 5(1), 368-375. https://doi.org/10.29121/granthaalayah.v5.i1.2017.1911

\section{Introduction}

Nowadays, learning English is as important as opening every door of opportunity along our journey of finding success. Necessarily, English has been in the atmosphere of our daily working stations. We meet various people; may be of different color and of different language. At present, people around the world use English to communicate with people from another country. English, as a language, is an essential tool to communicate. As much as it is widely used, it is significantly a medium to learn vast knowledge, help people in the work place, and create an understanding of the culture and the vision of the world community. English can bring good relations and cooperation with people in various countries. It has also helped develop learners to understand themselves and others better. 
Learning and understanding the differences of language and culture would lead to the immersion and assimilation of this to social, economic, and political paradigm of adaptation. Moreover, English is an important medium as we learn other areas of study such as Mathematics, Science, Computer Sciences and the like, which require learning Basic English Education throughout the course of study.

In Thailand, the Thai Basic Educational Core Curriculum B.E. 2551 (A.D. 2008) requires students to learn four strands of English language which are as follows: (1) Language for communication, (2) Language and culture language (3) Language and its relationship with other learning area, and (4) Language and its relationship with the community and the world (Ministry of Education, 2008). This design can help students to be able to communicate effectively with people around the world using the English language. In particular, reading is probably the most important skill for the student learning development because students basically use written texts in searching for information and acquiring new data of knowledge.

However, we have heard "How Thai students perform so poorly compared to those in other countries far and near. Not only that Thai students rank near the bottom in international standardized test scores, they even flunk national standardized tests year after year" and even "more than half (over $200 \mathrm{~K}$ or 59\%) of M.6 students who took the O-NET exam got just 10-20\% of the right answers in the English subject" Something has to be done to correct the problem. In this connection, reading can be a help to deal with the problem. Reading encourages the students learning vocabulary and develops their speaking and writing skills. It is the skill that Angwattanakul (1997) stated that "reading skill is important to get the knowledge and to help students in thinking skill and experience as well as entertainment." The reader can utilize these pros to develop and improve their lives and the society they are in. Reading is also one way that can help a person know the changes of the world. A person who has a good skill in reading can get the benefit from reading better than one who does no good at reading skill.

Moreover, Sichomphoo (1998:1) stated that "reading skill is more important than other skills for learners who studied English and used it as a second language anywhere in daily life's communication. It is also the skill useful for self-learning activities." Grabe and Stroller (1997:78-94) also stated that "reading is probably the most important skill for second language learning in academic contest." Furthermore, Jakpim (1992) said that "among the four skills student will have a chance to use, reading skill is the most. People who are proficient in reading English will benefit greatly from their reading." The studies of Paulston and Bruder (1982) and Deboer (1997:14-16) agreed that reading is the most necessary and important skill. Also, reading is a skill, to which students should pay more attention than any other skill. In addition, Pett (1982:23) pointed out that of all the four language skills, the skill that students always retain is reading.

The above studies results are consistent with the English reading achievement of grade ten students of Khowangwittayakhom School, when considering in details the English reading skill of the students is at the low level. The students need to be encouraged in reading activities in order to exercise their skill reading texts and to enhance reading comprehension. There are various methods of teaching language to encourage the students in reading comprehension. One of the most popular methods is Content -based Instruction (CBI) approach. The method is easy 
and beneficial to the learners in terms of reading comprehension. This teaching approach can be a more natural way of developing language ability. Therefore, the researcher is interested in studying English reading comprehension of grade ten students using Content-based Instruction (CBI) approach.

\section{Purpose of the Study}

Throughout the study, the researcher was aiming;

- To study students' achievement in reading taught by Content-based Instruction (CBI) approach.

- To study students' attitude toward using Content-based Instruction (CBI) approach to practice English reading skill.

\section{Research Questions}

- How does Content-based Instruction (CBI) approach help students to improve their achievement in reading comprehension?

- What are students' attitudes toward using Content-based Instruction (CBI) approach to practice English reading skill?

Scope of the Study

The scope of the study included 50 students from grade ten of Khowang wittayakhom School, Khowang district, Yasothon province during the first semester, academic year 2015. The 50 students were taken as a sample group of the study. A total of ten periods, fifty-five minutes per period for learning had been the time frame when the study was conducted.

\section{Significance of the Study}

The researcher believes that reading skill of students will have a significant improvement through reading comprehension activities implementing Content-based Instruction (CBI) approach. This research will also help the students to achieve a motivated, good, and positive attitude in reading English texts.

\section{Definitions of Key Terms}

There are several terms to be defined in this study which shows as follows:

- Reading skills. Reading skills are specific abilities which enable a reader to read the written from as meaningful language, to read anything written fluently. And to read, interact with the message.

- - Students refer to grade ten students of Kwowangwittayakhom School, Khowang district, Yasothon province.

- Reading Achievement means the ability of the students to understand the topic and learn vocabulary, grammar structures and idioms, which reflect on the reading score.

- Content-based Instruction (CBI) refers to an approach which is used to learn English through various of information to help learners understand better. 
- Reading Comprehension refers to the ability which the students are able to read accurately and effectively; to get the maximum knowledge and information from the text with the least misunderstand.

\section{Research Methodology}

\section{Population and Sample}

Population of this study was 186 of grade ten students who enrolled English course at Khowangwittayakhom School, Yasothon. It was 50 students randomly chosen out from the population as samples for the study.

\section{Research Design}

The research study was conducted on a one-group-pretest-posttest design. The samples took a pre-test to assess their understanding of the context before they studied CBI approach lesson plans. The ten CBI approach lesson plans were constructed by the researcher. After the implementation using CBI approach lesson plans, they took the post-test to compare and evaluate the level of their understanding and improvement. As part of the objectives of the study, the students answered the questionnaire to assess their attitude through CBI approach.

\section{Research Instruments}

In this study, instruments that were intellectually constructed consisted of CBI approach lesson plans, pre-test \& post-test and questionnaires.

- Content-based Instruction (CBI) Approach Lesson Plans

The lesson plans based on the CBI for ten periods (i.e., regular classroom periods). Firstly, the researcher studied from the basic Core Curriculum B.E. 2551 (A.D. 2008) to acquire knowledge for the research study. Researcher selected the theme, the topics and subtopics which were appropriated and related to the basic Core Curriculum B.E. 2551 (A.D. 2008) to tenth grade students, then chose 10 topics which were more familiar by the students. The topics were mainly derived from text books and the internet. The activities for each lesson plan were devised with contents that would make students participate and learn through different sources of knowledge. The researcher wrote 10 lesson plans for this particular study.

- Pre-test \& Post-test

A multiple-choice test was the instrument used to test students and to know the differences, improvement, and achievement level in reading before and after using reading exercises module designed for the research. In this study, the researcher constructed and developed the reading test by acquiring ideas from the Basic Education B.E. 2551 (B.E.) 2551 (A.D. 2008).The researcher constructed a 50-question reading tests with four multiple choices which had only one correct answer per question. Five experts in this field examined the accuracy the precision of language and checked its validity to ensure the content matched the objective. Furthermore, the researcher improved and tried it out for its effectiveness with 50 tenth grade students who were not part of the sample population. The researcher analyzed its difficulty and discrimination and 
selected the items which would present a level of difficulty (P) between 0.2-0.7 and discrimination $(\mathrm{R})$ of $0.25-0.73$.

- Questionnaire

The questionnaire was the instrument used to investigate the students' attitude towards using CBI approach. It consisted of 10 items. All items were done according to Likert's checklist type with the scales of 1 to 5 . Then, the questionnaire's validity was checked by the experts.

The five rating scales of the questionnaire according to students attitude were as follows:

5 means Absolutely Agree / 4 means Agree/ 3 means Uncertain / 2 means Disagree /

1 means Absolutely disagree

The criteria for interpretation of level by midpoint were as follows: $4.50-5.00$ means Absolutely Agree / 3.50 - 4.49 means Agree / 2.50 - 3.49 means Uncertain / 1.50 - 2.49 means Disagree / 1.00 -1.49 means Absolutely Disagree

\section{Data Collection}

A total of 50 of tenth grade students out of 186 students were selected by a simple random sampling technique. They were told that they would participate in a research project concerning reading English. The sample students took pretest before learning through 10 content-based instruction approach lesson plans to know their level of reading. There were three steps for each lesson. First, in the pre-reading step, the students had to find out difficult word and answered 2-4 questions. Second, in the while-reading step, the students read the text and tried to construct concept maps, find the main idea and give information. Lastly, in the post-reading step, the students identified information, compared their answers and presented their work. At the end of the study, the students took a post-test to examine their understanding.

\section{Data Analysis}

The collected data were analyzed by arithmetic mean (x), standard deviation (S.D.) and t-test by using Microsoft Excel 2010. In order to evaluate learning through content-based instruction approach, the researcher used arithmetic mean, standard deviation (S.D.) and t-test to compare the score of the pre-test and the post-test of the subjects who did the achievement test. The mean $(x)$ were used to examine the attitudes of students.

\section{Results and Discussions}

The result of this comparison between the pre-test and post-test score using dependent t-test was presented in Tables 1. 
Results from Achievement Test

Table 1: Result of Achievement Test

\begin{tabular}{|c|c|c|c|c|c|c|}
\hline $\begin{array}{l}\text { Reading } \\
\text { Achievement }\end{array}$ & $\underline{\mathbf{N}}$ & $\underline{\text { Min }}$ & $\underline{\text { Max }}$ & $\underline{\bar{X}}$ & $\underline{\text { S.D }}$ & $\underline{\mathbf{t}}$ \\
\hline Pre-test & 50 & 16 & 24 & 20.58 & 6.30 & \multirow{2}{*}{24.79} \\
\hline Post-test & 50 & 25 & 35 & 29.06 & 5.96 & \\
\hline
\end{tabular}

Table 1 above showed the minimum score of the pre-test was 16 and the maximum score was 25 . The minimum score of the post-test was 25 and the maximums score was 35 . The mean score of pre-test was 20.58, the standard deviation was 6.30 . After the subjects were taught by using CBI approach, they got higher scores. The mean score of the post-test was 29.06, the standard deviation was 5.96. According to the comparison between the pre-test and post-test score, after the subjects studied using CBI approach, their post-test score were higher than before studying at 0.05 levels of significance. This showed that the data accepted the hypothesis of this research. It meant that CBI approach could help the students to read and understand reading text. Therefore, the purpose of this research was successful.

Results from the Questionnaire

Table 2: Result from the Questionnaire

Item No.

1. I have learned vocabulary and grammar structure from the 10 contents.

2. The 10 contents help me gain various knowledge.

3. I like to be tested on reading comprehension.

4. I feel comfortable taking reading tests in English.

5. I use titles to help me figure out what a story is about.

6. Mind mapping help me understand the contents more.

7. I use context clues to help me guess the meaning of the text.

8. Reading skill is important in learning English.

9. Reading skill is important to my future.

10. The knowledge from 10 contents can be applied to my real life.

\section{Total}

\begin{tabular}{ll}
$\underline{\underline{X}}$ & Interpretation \\
4.58 & Absolutely Agree \\
4.10 & Agree \\
4.15 & Agree \\
4.07 & Agree \\
4.21 & Agree \\
4.32 & Agree \\
4.63 & Absolutely Agree \\
4.48 & Agree \\
4.28 & Agree \\
$\mathbf{4 . 3 1}$ & Agree \\
\hline
\end{tabular}

The table 2 above indicated that the mean score $(X)$ was 4.31. The interpretation was Agree. This showed that the data accepted the hypothesis of this research. It meant that CBI approach have made the positive attitude towards English reading.

\section{Discussion}

The use of CBI approach could help the 50 students in Khowangwittayakhom school improved their reading comprehension in reading that the result of this study seem to support Sinsap 
(2002) that studied the construction of English Supplementary Reading Materials Focusing on Content-Based Instruction (CBI) for Mattayom Suksa 6 students at Phothawattanasenee School, Rachaburi. The finding revealed that the materials worked effectively, the students' reading ability after the experiment was significantly higher than before the experiment and the students' opinions towards the ten unit English exercises were at a good level. It is also support Kwangsawad (2005: Abstract) that studied the implementation of content-based instruction in the EFL classroom through using cooperative learning, project work, simulation, role-plays, presentation, up-dated authentic materials, and graphic organizers to promote content and language learning. The study aimed to asses students' English skills. The samples were first-year English Education major students of Mahasarakham University. The data showed that content and language instruction was best developed through the use of cooperative learning and variety of activities. The research has shown that content-based instruction deserves being employed in the EFL classroom. Siriprasert (2009) also studied English Reading Achievement of MattayomSuksa 3 Students Taugh by Content-Based Instruction approach at Simuangwittayakham School, Ubon Ratchathani Province. The students' achievement in reading taught by content-based instruction approach was statistically higher than that before using the content-based instruction approach at 0.5 levels of significance. The research inferred that the content-based instruction approach which is used in the experiment helped the learner to achieve their learning process. The results of the present study showed that using CBI approach helped 50 students in Khowangwittayakhom school improved their reading comprehension in reading and made positive attitude towards English reading to them because the students have read various contents, have learned various vocabulary and have learned the structure of sentence through the contents.

\section{Conclusions \& Recommendations}

\section{Conclusion of the Study}

The purposes of this study were to investigate the students' achievement in reading taught by Content-Based Instruction (CBI) approach and to study the attitude of students through the approach. The samples of the study were 50 of grade ten students who enrolled English course at Khowangwittayakhom School, Yasothorn province. The samples are selected by a simple random sampling. The instrument used in this study consisted of ten content-based instruction lesson plan, reading test, and questionnaire. To achieve the first purpose the samples group took pretest, then learned through ten content-based instruction lesson plans. They studied 10 contents that consist of Checking out second-hand city, The Education system of the UK and the USA, Internet shopping, Candle festival in Ubon Ratchathani, New year cheer, Songkran, Mountain mummies, Fingerprints, Chiang Mai Night Bazaar and the Golden Triangle. After that, students took the post-test. The data analysis showed that all of the students got the scores in the post-test higher than the pre-test. To achieve the second purpose, students checked their positive attitude in reading English through CBI approach by using questionnaire. The data analysis showed that CBI approach had made the positive attitude towards English reading. As a result, the finding of the study indicated that CBI approach could help the 50 students in Khowangwittayakhom School to improve their reading comprehension in reading and made positive attitude towards English reading skill. 


\section{Recommendation for further studies}

Recommendation for further study show as followed:

- Subjects in a further study should be undertaken with all students in the school that take course in English subject.

- A similar study should be carried with students at other levels.

- A further study should use different contents based on students' background and interests.

\section{Acknowledgements}

This independent study accomplished with the assistance of many people. First of all, I would like to express my deepest thanks and my sincere gratitude to my advisor, Nutprapha Kongphet Dennis, Ph.D. for her valuable recommendations and intellectual support in this study. My highest respect is devoted to all of the instructors of the Humanities and Social Science of Ubon Ratchathani Rajabhat University, who provided me the knowledge and guidance for this study. I also express my thanks to the students and teachers in Khowangwittayakhom School for their support and encouragement. Finally, I would like to extend my deepest thanks to my beloved family for their encouragement and love. I would like to devote all the benefits from this study to all the instructors and others involved.

\section{References}

[1] Angwattanakul,S. Research in Learning and Teaching English :Bangkok . Chulalongkorn University, 1992.

[2] Deboer, j.j. The Teaching of Reading. Catcatta : Oxford \& IBH, 1997.

[3] Grabe, W, and F.L. Stroller. Content-Based Classroom: Research Foundations. New York: Longman, 1997.

[4] Jakpim, C. The Comparism of Achievement in English Reading Comprehension of Mattayom Suksa 5. Between Whole Class and Cooperative Learning Groups. Master's Thesis Srinakharinvirote University, 1992.

[5] Kwangsawad, T. The implementation of Content-based Instruction in The EFL Classroom through Using Cooperative Learning, Project work, Simulation Role-plays, Debates, presentation, Up-Dated Authentic Materials, and Graphic Organizers to Promote Content and Language Learning. Master's Thesis. Mahasarakham University, 2005.

[6] Paulton, Bratt, C. and Bruder, M.N. Teaching English as a second Language: Techniques and Procedures . Cambridge : Cambridge University, 1982.

[7] Pett, j. English Teaching Forum, 3. Reading: An ESL Skill at University. N.p, 1982.

[8] Sichomphoo. A Comparison of Mattayom Suksa 3 Students Understanding and Reading Influence in English Through the Instruction of DR-TA and the Teacher's Manual. Master's Thesis. Srinakarinwirote University, 1999.

[9] Sinsap, S. The Construction of English Supplementary Reading Materials Focusing on ContentBased Instruction (CBI) for Mattayomsuksa 6 Students Phothawattanasenee School Ratchaburi. Master's Thesis. Silapakorn University, 2002.

[10] Siriprasert, S. English Reading Achievement of MattayomSuksa 3 Students Taught by Contented Based Instruction Approach. Ubonratchathani Rajabhat University, 2009.

*Corresponding author.

E-mail address: nootprapa@gmail.com 